\title{
PREVALENCE AND CORRELATES OF ACTIVE TRAVELING TO SCHOOL AMONG ADOLESCENTS IN CYPRUS
}

\author{
Constantinos A. Loucaides ${ }^{1,2}$, Russell J ago ${ }^{3}$, Maria Theophanous ${ }^{4}$ \\ ${ }^{1}$ Centre of Educational Research and Evaluation, Ministry of Education and Culture, Nicosia, Cyprus \\ ${ }^{2}$ Department of Education, The Open University of Cyprus, Nicosia, Cyprus \\ ${ }^{3}$ Department of Exercise, Nutrition and Health Sciences, University of Bristol, Bristol, U.K. \\ ${ }^{4}$ Cyprus Pedagogical Institute, Ministry of Education and Culture, Nicosia, Cyprus
}

\begin{abstract}
SUMMARY
More data regarding prevalence and correlates of active travel to school are needed from different parts of the world. The purpose of this study was to examine prevalence and correlates of active travel to school among adolescents in Cyprus. A cross-sectional study was conducted among 1966 adolescents attending grade 6 , grades 7-9, grades 10-12 and technical/vocational schools in Cyprus. Overall prevalence of active travel to school was 19.4\%. Parental perceptions of safe route to school, other children walking to school from the child's neighborhood and school location (urban versus rural) were associated with active travel across different levels of education. Having enough time to walk to school in the morning was the most consistent correlate of active travel. Low prevalence estimates of active traveling to school among adolescents in Cyprus raise the need to promote this source of daily physical activity.
\end{abstract}

Key words: Cyprus, adolescents, active travel, commute, correlates

Address for correspondence: C. A. Loucaides, 77 Larnaca Avenue, Aglanjia, 2102, Nicosia, Cyprus. E-mail: conlou@ avacom.net

\section{INTRODUCTION}

Physical activity (PA) has been shown to have beneficial effects on young peoples' musculoskeletal health and several components of cardiovascular health (1). PA is likely to be important for the prevention of overweight and obesity observed among young people (2). Active travel to school has been proposed as a source of children's PA $(3,4,5)$ and studies suggest that active travel to school is associated with higher PA levels during the whole day $(6,7)$. Promoting active transport to school is especially important because recent evidence indicates that travel to school has shifted from active to inactive modes (8). Information regarding the prevalence and factors associated with active travel to school are the first steps in promoting this source of children's PA.

Prevalence estimates of active traveling to school including walking and bicycling vary between countries. A study conducted in the United States among secondary school students indicated that between $6.4 \%$ and $12.1 \%$ actively travel to school (9) while findings from a study in Canada suggest that $42.5 \%$ of secondary school students actively travel to school (10). Studies from Australia indicate that between $25.5 \%$ and $46.0 \%$ of elementary school children actively travel to school $(8,11,12)$ while in the Philippines $36.6 \%$ of secondary school girls and $46.8 \%$ of boys report active traveling to school (13).

Data from different European countries show that $43.5 \%$ of British elementary school children (14) and $47.0 \%$ of Dutch secondary school children actively travel to schools (15). The highest prevalence estimates of active traveling to school come from Switzerland and Denmark with $78.0 \%$ of Swiss elementary and secondary school children (16) and 64.1\% of elementary and $86.4 \%$ of secondary school children from Denmark reporting either walking or cycling to school (17). More data regarding prevalence estimates of active traveling to school are needed as most of these studies employed samples from one area and did not include children from elementary, middle and high schools.

A number of studies have also examined correlates of active traveling to schools. Parental perceptions of few other children in the neighborhood (18), parental safety concerns regarding routes to school $(12,16,19)$ and objectively assessed busy roads to school $(16,18)$ have been found to be negatively associated with active traveling to school. Distance to school and walk travel time is the most consistent correlate of active traveling to school with children living closer to schools more likely to actively travel $(12,15,16,18,20)$.

No studies to date have examined the prevalence and correlates of active traveling to school among Cypriot adolescents. Cyprus is a country member of the European Union and is situated in the Eastern Mediterranean. To our knowledge, no studies have been conducted to examine prevalence and correlates of active travel to school in southern European countries situated in the Mediterranean region. This is especially important as recent reviews have suggested that more evidence regarding environmental correlates of active traveling to school are needed from varied environments and settings including Europe (21) and more studies from children and adolescents living in other countries are warranted (22). Results from this population could strengthen existing evidence and enhance efforts to promote active travel to school. Further, inconclusive evidence exists as to the associa- 
tion between active traveling to school, PA and weight status (7, 23). Therefore, the purpose of the present study was twofold: 1 . to examine the prevalence of active traveling to school among different subgroups of adolescents in Cyprus and 2. examine potential personal, social and environmental correlates of active traveling to school among this population.

\section{MATERIALS AND METHODS}

\section{Participants}

Twenty five schools from all five districts under the control of the Republic of Cyprus including nine elementary schools (grade 6), six middle schools (grades 7-9), five high schools and five technical education schools (grades 10-12) were invited to participate in this study $(\mathrm{N}=1966)$. Technical education schools offer vocational rather than academic training and students can follow this direction after the end of the 9th grade (middle school) or alternatively follow the academic route (high school or lyceum). All 6th grade children from the elementary schools and randomly selected classes (class numbers were mixed and numbers drawn) from middle, high and technical education schools completed questionnaires. Questionnaires were completed during class time. The protocol for this study was approved by the Cyprus Pedagogical Institute and is part of a larger study that examined students' health behaviors conducted by the Ministry of Education.

\section{Measures}

Students' mode of travel to school was assessed with one item asking students to indicate how they usually traveled from home to school with four response options including bus or car, motorcycle, bicycle, and walk. Four items were also used to assess weekly participation in moderate and vigorous PA. Two items assessed frequency per week that students participated in moderate ('PA that does not make you sweat or breathe hard such as walking, slow bicycling and volleyball'), and vigorous PA ('PA that makes you sweat and breathe hard such as running, playing basketball, playing football and swimming'). Eight response options were provided ranging from 'not at all' to 'seven days'. Two further items asked students to indicate the usual duration of moderate and vigorous activities with four response options including 'up to 30 minutes', 'up to one hour', 'up to one and a half hour' and 'more than one and a half hour'. These items were adopted from a previous study that also examined correlates and prevalence of active traveling to school (9).

Eight items were used to examine perceived social and environmental correlates of active traveling to school. Students were asked to indicate their degree of agreement with statements including 'There is a lot of traffic on the way to school', 'There are four-way intersections on the way to school', 'There are sidewalks on the way to school', 'I feel safe to walk from home to school', 'There are children in my neighborhood that walk to school', 'My parents think that it is safe for me to walk to school', 'I have enough time in the morning to walk to school', and 'The distance from home to school is big'. Responses for these items were on a five point scale ranging from 'not at all' to 'very much'. Middle school, secondary school and technical school students also reported their weight, height and date of birth for the calculation of their Body Mass Index [BMI, weight $(\mathrm{kg}) /$ height $^{2}\left(\mathrm{~m}^{2}\right)$ ]. Elementary school students' weight and height were measured by the first and third author using a portable stadiometer (SECA 220, Hamburg, Germany) and digital scale (SECA 767, Hamburg, Germany).

\section{Data Treatment and Analysis}

Students were classified as active if they participated in PA of at least moderate intensity for one hour per day (24). Children's BMI was calculated and extreme outliers with BMIs under 8 or over 40 were removed from the analyses (25). Children were classified as normal weight and overweight or obese based on international cut-off points developed by the International Obesity Task Force (26). Children were classified as active travelers to school if they reported as usual mode of travel to school walk or bicycle and non-active travelers if they reported as usual mode of travel bus or car, and motorcycle. Chi-squared tests were computed to examine potential differences in the percentages of children who actively traveled to school across gender, school location (urban versus rural), weight status and PA status.

Bivariate logistic regression analyses were conducted with travel mode status (active versus non-active traveling to school) as the dependent variable and each of the personal, social and environmental correlates as the independent variables. Variables with significant association with active traveling to school at the bivariate level were then entered in a multivariate logistic regression model. All analyses were conducted separately for each level of education and for the whole sample. As the children were nested in schools, robust standard errors (Huber-White sandwich estimates) which control for the clustering within schools were employed using the Complex Samples procedure in SPSS, Version 17.0. Alpha was set at 0.05 .

\section{RESULTS}

Table 1 presents the characteristics of the sample stratified by level of education.

A significant difference in active traveling to school was observed among the four levels of education $\left[\chi^{2}(3)=25.8, p<0.001\right]$. Similar proportions of grade six children (22.6\%), middle school children (21.2\%) and high school children (21.1\%) reported active traveling to school, but only $9.9 \%$ of children from technical schools reported active traveling to school.

In Table 2 potential differences in travel mode to school among gender, school location, weight status and PA for each level of education and the whole sample are presented. A higher proportion of sixth-grade boys reported active traveling to school in comparison to sixth grade girls $\left[\chi^{2}(1)=4.0, \mathrm{p}<0.05\right]$ and a higher proportion of normal weight students from technical schools reported active traveling to school in comparison to overweight students $\left[\chi^{2}(1)=5.4, p<0.05\right]$. Students in middle schools $\left[\chi^{2}(1)\right.$ $=5.2, \mathrm{p}<0.05]$ and high schools $\left[\chi^{2}(1)=15.6, \mathrm{p}<0.001\right]$ living in urban areas were more likely to report active traveling to school in comparison to students living in rural areas. Physically active students from elementary schools $\left[\chi^{2}(1)=4.5, p<0.05\right]$ and high schools $\left[\chi^{2}(1)=7.5, p<0.01\right]$ were more likely to report active traveling to school in comparison to inactive students. 
Table 1. Characteristics of the sample by level of education

\begin{tabular}{|c|c|c|c|c|c|}
\hline & $\begin{array}{c}\text { Elementary school } \\
\text { (grade 6) } \\
(n=448)\end{array}$ & $\begin{array}{c}\text { Middle school } \\
\text { (grades 7-9) } \\
(n=656)\end{array}$ & $\begin{array}{c}\text { High school } \\
\text { (grades 10-12) } \\
(n=479)\end{array}$ & $\begin{array}{c}\text { Technical school } \\
\text { (grades 10-12) } \\
(n=383)\end{array}$ & $\begin{array}{l}\text { Total sample } \\
\quad(n=1966)\end{array}$ \\
\hline \multicolumn{6}{|l|}{ Gender - n (\%) } \\
\hline Boys & $220(49.4)$ & $332(50.8)$ & $166(34.7)$ & $309(80.7)$ & $1027(52.4)$ \\
\hline Girls & $225(50.6)$ & $321(49.2)$ & $312(65.3)$ & $74(19.3)$ & $932(47.6)$ \\
\hline \multicolumn{6}{|l|}{ District $^{3}-n(\%)$} \\
\hline Nicosia & $131(29.2)$ & $291(44.4)$ & $166(34.7$ & $118(30.8)$ & $706(35.9)$ \\
\hline Lemesos & $104(23.2)$ & $143(21.8)$ & $125(26.1)$ & $105(27.4)$ & $477(24.3)$ \\
\hline Larnaca & $101(22.5)$ & $100(15.2)$ & $64(13.4)$ & $63(16.4)$ & $328(16.7)$ \\
\hline Paphos & $76(17.0)$ & $58(8.8)$ & $63(13.2)$ & $60(15.7)$ & $257(13.1)$ \\
\hline Ammochostos & $36(8.0)$ & $64(9.8)$ & $61(12.7)$ & $37(9.7)$ & $198(10.1)$ \\
\hline \multicolumn{6}{|l|}{ Location - $n(\%)$} \\
\hline Urban & $300(67.0)$ & $592(90.2)$ & $418(87.3)$ & $346(90.3)$ & $1656(84.2)$ \\
\hline Rural & $148(33.0)$ & $64(9.8)$ & $61(12.7)$ & $37(9.7)$ & $310(15.8)$ \\
\hline Age - mean (sd) & $11.8(0.4)$ & $13.9(0.9)$ & $16.7(0.9)$ & $16.9(1.0)$ & $14.7(2.2)$ \\
\hline Weight (kg) - mean (sd) & $45.5(11.4)$ & $55.8(12.4)$ & $61.9(14.7)$ & $69.0(15.0)$ & $57.5(15.5)$ \\
\hline Height (m) - mean (sd) & $1.50(0.07)$ & $1.64(0.09)$ & $1.69(0.09)$ & $1.74(1.0)$ & $1.64(0.12)$ \\
\hline BMI - mean (sd) & $20.1(4.0)$ & $20.7(3.8)$ & $21.5(3.7)$ & $22.8(4.3)$ & $21.1(4.0)$ \\
\hline \multicolumn{6}{|l|}{ Weight status - $n(\%)$} \\
\hline Normal weight & $285(69.3)$ & $487(79.3)$ & $355(82.9)$ & $235(68.7)$ & $1362(75.9)$ \\
\hline Overweight & $126(30.7)$ & $127(20.7)$ & $73(17.1)$ & $107(31.3)$ & $433(24.1)$ \\
\hline \multicolumn{6}{|l|}{ Travel mode - $n(\%)$} \\
\hline Bus or car & $339(77.4)$ & $479(74.8)$ & $343(73.8)$ & $286(79.0)$ & $1447(76.0)$ \\
\hline Motorcycle & - & $25(3.9)$ & $24(5.2)$ & $40(11.0)$ & $89(4.7)$ \\
\hline Bicycle & $7(1.6)$ & $6(0.9)$ & $5(1.1)$ & $7(1.9)$ & $25(1.3)$ \\
\hline Walk & $92(21.0)$ & $130(20.3)$ & $93(20.0)$ & $29(8.0)$ & $344(18.1)$ \\
\hline
\end{tabular}

aln Cyprus there are six districts and participants for this study were from the five districts under the control of the Republic of Cyprus (except the district of Keryneia)

Table 2. Number and percentage of participants by level of education, travel mode to school and personal characteristics

\begin{tabular}{|c|c|c|c|c|c|c|c|c|c|c|}
\hline & \multicolumn{2}{|c|}{$\begin{array}{c}\text { Elementary school } \\
\text { (grade 6) }\end{array}$} & \multicolumn{2}{|c|}{$\begin{array}{l}\text { Middle school } \\
\text { (grades 7-9) }\end{array}$} & \multicolumn{2}{|c|}{$\begin{array}{l}\text { High school } \\
\text { (grades 10-12) }\end{array}$} & \multicolumn{2}{|c|}{$\begin{array}{l}\text { Technical school } \\
\text { (grades 10-12) }\end{array}$} & \multicolumn{2}{|c|}{ Total sample } \\
\hline & $\begin{array}{l}\text { Active } \\
\text { travel } \\
\mathrm{n}(\%)\end{array}$ & $\begin{array}{c}\text { Non-active } \\
\text { travel } \\
\mathrm{n}(\%)\end{array}$ & $\begin{array}{l}\text { Active } \\
\text { travel } \\
\mathrm{n}(\%)\end{array}$ & $\begin{array}{c}\text { Non-active } \\
\text { travel } \\
n(\%)\end{array}$ & $\begin{array}{l}\text { Active } \\
\text { travel } \\
n(\%)\end{array}$ & $\begin{array}{c}\text { Non-active } \\
\text { travel } \\
n(\%)\end{array}$ & $\begin{array}{l}\text { Active } \\
\text { travel } \\
n(\%)\end{array}$ & $\begin{array}{c}\text { Non-active } \\
\text { travel } \\
n(\%)\end{array}$ & $\begin{array}{l}\text { Active } \\
\text { travel } \\
\mathrm{n}(\%)\end{array}$ & $\begin{array}{c}\text { Non-active } \\
\text { travel } \\
n(\%)\end{array}$ \\
\hline \multicolumn{11}{|l|}{ Gender } \\
\hline Boys & $57(26.9)$ & $155(73.1)$ & $69(21.4)$ & $253(78.6)$ & $40(25.2)$ & $119(74.8)$ & $30(10.4)$ & $259(89.6)$ & $196(20.0)$ & $786(80.0)$ \\
\hline Girls & $42(18.8)$ & $181(81.2)^{b}$ & $66(21.0)$ & $249(79.0)$ & $58(19.0)$ & $247(81.0)$ & $6(8.2)$ & $67(91.8)$ & $172(18.8)$ & $744(81.2)$ \\
\hline \multicolumn{11}{|l|}{ Location } \\
\hline Urban & $64(22.0)$ & $227(78.0)$ & $130(22.5)$ & $449(77.5)$ & $97(24.0)$ & $308(76.0)$ & $33(10.2)$ & $292(89.8)$ & $324(20.3)$ & $1276(79.8)$ \\
\hline Rural & $35(23.8)$ & $112(76.2)$ & $6(9.8)$ & $55(90.2)^{b}$ & $1(1.7)$ & $59(98.3)^{d}$ & $3(8.1)$ & $34(91.9)$ & $45(14.8)$ & $260(85.2)^{b}$ \\
\hline \multicolumn{11}{|l|}{ Weight status } \\
\hline Normal & $65(23.2)$ & $215(76.8)$ & $100(20.9)$ & $379(79.1)$ & 66 (19.2) & $277(80.8)$ & $24(10.8)$ & $199(89.2)$ & $255(19.2)$ & $1070(80.8)$ \\
\hline Overweight & $28(22.8)$ & $95(77.2)$ & $27(22.1)$ & $95(77.9)$ & $20(27.8)$ & $52(72.2)$ & $3(3.0)$ & $97(97.0)^{b}$ & $78(18.7)$ & $339(81.3)$ \\
\hline \multicolumn{11}{|l|}{$P A^{a}$} \\
\hline Active & $71(25.8)$ & $204(74.2)$ & $81(21.6)$ & $294(78.4)$ & $47(27.5)$ & $124(72.5)$ & $18(11.5)$ & $139(88.5)$ & $217(22.2)$ & $761(77.8)$ \\
\hline Inactive & $27(17.0)$ & $132(83.0)^{b}$ & $51(20.3)$ & $200(79.7)$ & $47(16.7)$ & $234(83.3)^{c}$ & $16(8.2)$ & $180(91.8)$ & $141(15.9)$ & $746(84.1)^{c}$ \\
\hline
\end{tabular}

${ }^{a} \mathrm{PA}=$ Physical activity; ${ }^{\mathrm{D} S}$ Significant difference at the $p<0.05$ level; ${ }^{\circ}$ Significant difference at the $p<0.01$ level; dSignificant difference at the $p<0.001$ level 
Table 3. Associations between active travel to school and personal and perceived social and environmental factors by level of education

\begin{tabular}{|c|c|c|c|c|c|c|c|c|}
\hline & \multicolumn{2}{|c|}{$\begin{array}{c}\text { Elementary school } \\
\text { (grade 6) }\end{array}$} & \multicolumn{2}{|c|}{$\begin{array}{c}\text { Middle school } \\
\text { (grades 7-9) }\end{array}$} & \multicolumn{2}{|c|}{$\begin{array}{c}\text { High school } \\
\text { (grades 10-12) }\end{array}$} & \multicolumn{2}{|c|}{$\begin{array}{c}\text { Technical school } \\
\text { (grades 10-12) }\end{array}$} \\
\hline & $\begin{array}{c}\text { Unadjusted OR } \\
(95 \% \mathrm{Cl})^{\mathrm{a}}\end{array}$ & $\begin{array}{c}\text { Adjusted OR } \\
(95 \% \mathrm{CI})\end{array}$ & $\begin{array}{c}\text { Unadjusted OR } \\
(95 \% \mathrm{CI})\end{array}$ & $\begin{array}{l}\text { Adjusted OR } \\
(95 \% \mathrm{Cl})\end{array}$ & $\begin{array}{c}\text { Unadjusted OR } \\
(95 \% \mathrm{Cl})\end{array}$ & $\begin{array}{c}\text { Adjusted OR } \\
(95 \% \mathrm{Cl})\end{array}$ & $\begin{array}{c}\text { Unadjusted OR } \\
(95 \% \mathrm{CI})\end{array}$ & $\begin{array}{c}\text { Adjusted OR } \\
(95 \% \mathrm{Cl})\end{array}$ \\
\hline \multicolumn{9}{|l|}{ Gender } \\
\hline Girls & Referent & - & Referent & - & Referent & - & Referent & - \\
\hline Boys & $1.6(1.0-2.6)$ & & $1.0(0.5-2.0)$ & & $1.4(0.8-2.4)$ & & $1.3(0.3-5.1)$ & \\
\hline \multicolumn{9}{|l|}{ Location } \\
\hline Rural & Referent & - & Referent & Referent & Referent & Referent & Referent & - \\
\hline Urban & $0.9(0.3-2.5)$ & & $2.6(1.7-4.1)^{\mathrm{e}}$ & $2.2(1.7-2.9)^{\mathrm{e}}$ & $18.4(15.5-21.8)^{f}$ & $10.6(8.5-13.2)^{f}$ & $1.3(1.0-1.7)$ & \\
\hline \multicolumn{9}{|l|}{ Weight status } \\
\hline Overweight & Referent & - & Referent & - & Referent & - & Referent & - \\
\hline Normal weight & $1.0(0.7-1.5)$ & & $0.9(0.5-1.7)$ & & $0.6(0.3-1.2)$ & & $3.9(1.0-15.7)$ & \\
\hline \multicolumn{9}{|l|}{$\mathrm{PA}^{\mathrm{b}}$} \\
\hline Inactive & Referent & - & Referent & - & Referent & Referent & Referent & \\
\hline Active & $1.7(0.9-3.2)$ & & $1.1(0.8-1.5)$ & & $1.9(1.1-3.1)^{d}$ & $1.6(0.9-2.9)$ & $1.5(0.4-5.9)$ & - \\
\hline Big distance ${ }^{c}$ & $0.7(0.5-0.9)^{d}$ & $1.1(0.7-1.6)$ & $0.7(0.5-1.0)^{d}$ & $0.8(0.6-1.2)$ & $0.7(0.4-1.1)$ & - & $0.8(0.6-1.2)$ & - \\
\hline Intersections $^{c}$ & $0.7(0.5-1.0)^{d}$ & $0.8(0.5-1.2)$ & $0.7(0.5-1.1)$ & - & $0.8(0.4-1.5)$ & - & $1.0(0.6-1.6)$ & - \\
\hline $\begin{array}{l}\text { I feel safe to } \\
\text { walkc }^{\text {c }}\end{array}$ & $2.1(1.5-3.0)^{\mathrm{e}}$ & $1.2(0.9-1.6)$ & $1.3(1.0-1.7)^{d}$ & $0.9(0.7-1.2)$ & $1.5(1.0-2.2)^{d}$ & $1.1(1.0-1.3)$ & $1.4(1.0-1.9)$ & - \\
\hline $\begin{array}{l}\text { Other children } \\
\text { walk }^{c}\end{array}$ & $1.5(1.1-1.9)^{\mathrm{e}}$ & $1.3(1.1-1.6)^{\mathrm{e}}$ & $1.4(1.2-1.5)^{e}$ & $1.1(0.9-1.3)$ & $1.4(0.7-2.7)$ & - & $1.2(0.9-1.7)$ & - \\
\hline $\begin{array}{l}\text { My parents } \\
\text { think it's safec }\end{array}$ & $2.6(1.9-3.7)^{f}$ & $1.8(1.3-2.5)^{\mathrm{e}}$ & $1.8(1.5-2.2)^{f}$ & $1.5(1.1-2.0)^{d}$ & $1.5(1.0-2.3)$ & - & $1.3(1.1-1.6)^{\mathrm{e}}$ & $1.1(0.8-1.5)$ \\
\hline $\begin{array}{l}\text { I have enough } \\
\text { time to walkc }\end{array}$ & $2.8(2.0-3.8)^{f}$ & $2.0(1.5-2.9)^{e}$ & $2.0(1.6-2.5)^{f}$ & $1.8(1.4-2.3)^{\mathrm{e}}$ & $2.2(1.3-3.8)^{d}$ & $2.0(1.3-3.1)^{d}$ & $1.9(1.3-2.6)^{\mathrm{e}}$ & $1.9(1.2-2.8)^{d}$ \\
\hline
\end{tabular}

Note: The variables 'There is a lot of traffic on the way to school' and 'There are sidewalks on the way to school' are not included in this table as no significant associations were observed at the bivariate analyses with active travel across the four levels of education. ${ }^{\mathrm{a}} \mathrm{OR}=$ Odds ratio; $\mathrm{Cl}=\mathrm{Confidence}$ interval; ${ }^{\mathrm{b}} \mathrm{PA}=\mathrm{Physical}$ activity;

'Variables measured on a five-point scale ranging from 'not at all' to 'very much', dSignificant association at the $p<0.05$ level; eSignificant association at the $p<0.01$ level; 'Significant association at the $p<0.001$ level

At the multivariate level (Table 3), students from elementary schools who reported that they had enough time in the morning to walk to school (OR=2.0, 95\% CI: 1.5-2.9) whose parents felt that it was safe to walk to school $(\mathrm{OR}=1.8,95 \% \mathrm{CI}: 1.3-2.5)$ and who reported that there are children in their neighborhood that walk to school (OR=1.3, 95\% CI: $1.1-1.6)$ were more likely to be active travelers. Middle school students who lived in urban areas (OR=2.2, 95\% CI: 1.7-2.9), who reported that they had enough time in the morning to walk to school $(\mathrm{OR}=1.8,95 \% \mathrm{CI}$ : 1.4-2.3) and whose parents felt that it was safe to walk to school (OR=1.5, 95\% CI: 1.1-2.0) were more likely to walk to school. High school students who lived in urban areas were also more likely to be active travelers (OR=10.6, 95\% CI: 8.5-13.2) as well as those who reported that they had enough time in the morning to walk to school (OR=2.0, 95\% CI: 1.3-3.1). Having enough time in the morning to walk to school was the only variable for technical school students positively associated with active travel (OR=1.9, 95\% CI: 1.2-2.8). Table 4 presents correlates of active traveling to school across the whole sample. Students who reported having enough time in the morning to walk to school (OR=1.9, 95\% CI: 1.7-2.1) and who thought that their parents felt that it was safe for them to walk to school $(\mathrm{OR}=1.5,95 \% \mathrm{CI}$ : $1.3-1.7)$ were more likely to be active travelers. Students who reported that the distance from their home to school was big were less likely to walk to school (OR=0.9, 95\% CI: 0.8-1.0).

\section{DISCUSSION}

This is the first study to assess prevalence and correlates of active traveling to school in a national sample of Greek children in Cyprus. Prevalence estimates from this study suggest that overall, 19.4\% of Cypriot adolescents actively travel to school. These prevalence estimates are lower than those reported in many other countries including England (14), Holland (15), Switzerland (16), Denmark (17), and Canada (10) but similar to prevalence estimates from Australia $(8,11,12)$ and higher than the US (9). Low prevalence estimates of active traveling to schools among Cypriot adolescents may be attributed to the high car ownership in Cyprus as International data indicate that Cyprus holds the highest car ownership rate in the world with 742 cars per 1,000 people (27). Our findings suggest that there is a need to promote active traveling to school among adolescents in Cyprus. 
Table 4. Associations between active travel to school and personal and perceived social and environmental factors across the whole sample

\begin{tabular}{|c|c|c|}
\hline & \multicolumn{2}{|c|}{ Whole sample ( $n=1865$ ) } \\
\hline & $\begin{array}{c}\text { Unadjusted OR } \\
(95 \% \mathrm{Cl})^{\mathrm{a}}\end{array}$ & $\begin{array}{c}\text { Adjusted OR } \\
(95 \% \mathrm{Cl})\end{array}$ \\
\hline \multicolumn{3}{|l|}{ Gender } \\
\hline Boys & Referent & -- \\
\hline Girls & $1.1(0.8-1.5)$ & \\
\hline \multicolumn{3}{|l|}{ Location } \\
\hline Rural & Referent & -- \\
\hline Urban & $1.5(0.6-3.4)$ & \\
\hline \multicolumn{3}{|l|}{ Weight status } \\
\hline Normal weight & Referent & $--\cdot$ \\
\hline Overweight & $1.0(0.7-1.5)$ & \\
\hline \multicolumn{3}{|l|}{$P^{b}$} \\
\hline Inactive & Referent & Referent \\
\hline Active & $1.5(1.1-2.0)^{\mathrm{e}}$ & $1.2(0.9-1.6)$ \\
\hline A lot of traffic & $1.0(0.8-1.1)$ & $\cdots$ \\
\hline Big distance ${ }^{c}$ & $0.7(0.6-0.8)^{f}$ & $0.9(0.8-1.0)^{d}$ \\
\hline Intersections $^{c}$ & $0.7(0.6-0.9)^{e}$ & $0.9(0.7-1.0)$ \\
\hline Sidewalks ${ }^{c}$ & $1.1(1.0-1.3)$ & --- \\
\hline I feel safe to walkc & $1.6(1.4-1.8)^{f}$ & $1.0(0.9-1.1)$ \\
\hline Other children walkc & $1.4(1.2-1.6)^{f}$ & $1.1(1.0-1.3)$ \\
\hline My parents think it's safe ${ }^{c}$ & $1.8(1.6-2.1)^{f}$ & $1.5(1.3-1.7)^{f}$ \\
\hline I have enough time to walk & $2.2(1.9-2.4)^{f}$ & $1.9(1.7-2.1)^{f}$ \\
\hline
\end{tabular}

${ }^{\mathrm{a}} \mathrm{OR}=$ Odds ratio $\mathrm{Cl}=$ Confidence interval; ${ }^{\mathrm{b} P A}=$ Physical activity; ${ }^{\mathrm{c}}$ Variables measured on a five-point scale ranging from 'not at all' to 'very much'; 'Significant association at the $p<0.05$ level; eSignificant association at the $p<0.01$ level; fSignificant association at the $p<0.001$ level

Of interest is the low percentage of students in technical schools who reported active traveling to schools (9.9\%). In Cyprus, there are only 14 technical schools in comparison to 346, 70 and 38 elementary, middle and high schools respectively, and therefore, students attending technical school need to travel longer distances to reach their schools. Distance and travel time to school have been shown to be the strongest factors that affect the decision to walk to school (20). In September 2008, the Ministry of Communications and Works of the Republic of Cyprus has initiated the 'School Bus' program where a number of bus routes were created so that middle and secondary school children could travel to school by public transport (28). The main purpose of this initiative was to decrease traffic congestion around schools. Active travel time could also be added into this effort if, for example, school buses stop some distance from school so that students could also walk to school.

In the present sample, elementary and high school students walking to school were more likely to be classified as physically active than inactive. Results of studies utilizing objective measures of PA show more consistent positive associations between PA and active travel (23) than studies utilizing self-reports (7). Findings of the present study that used a self-report measure of PA suggest that the promotion of active traveling to school may also help promote children's overall PA levels.
Technical school students who walked to school were more likely to be normal weight than overweight. Literature reviews on the association between active travel to school and overweight have concluded that there are not sufficient evidence to support any association between active traveling to school and overweight in schoolchildren $(7,23)$. A longitudinal study also assessing the association between active traveling and overweight indicated that active traveling to school over a 2-year period, was not associated with BMI change or overweight status (29). While the findings of the present study could support an association between active travel and overweight, the small sample size of children in the analysis limit the strength of this finding.

Middle and high school students living in urban areas were more likely to actively travel to school in comparison to those living in rural areas. This finding was also observed in the multivariate analyses where middle and high school students living in urban areas were more than two times and more than ten times as likely respectively to walk to schools in comparison to their counterparts living in rural areas. These findings are in agreement with studies from the United States (30), Australia (12) and Canada (10). The lack of middle and secondary schools in small rural communities means that these students need to travel by car or bus to their schools. Interestingly, in the multivariate analyses, more significant associations were observed with perceived social and environmental correlates of active traveling than with personal variables.

In the multivariate analyses, the most consistent correlate of active traveling to school among all levels of education was enough time to walk to school. Students who stated that they had enough time in the morning to walk to school were more likely to be active travelers. This finding could be explained by the big distance from home to school and thus travel time that students need to dedicate to travel to school. Interestingly however, no significant associations at the multivariate level were revealed between active travel to school and the variable 'The distance from home to school is big' (a significant association was observed for the whole sample analyses but not for the level of education-specific analyses). This finding is in contrast to previous studies across many countries that indicate that distance to school is the most consistent correlate of active traveling to school $(12,15,18,20)$. A possible explanation might be that previous studies have used objective measures of distance including Geographical Information Systems $(16,18)$. Nevertheless, availability of travel time and big distance from school were negatively associated in the present study (Spearman's $\rho=-0.25, \mathrm{p}<0.001$ ), something that might indicate that distance to school may indeed be an important factor regarding traveling decision to school in the Cypriot context.

Students from elementary and middle schools who indicated that their parents thought that it was safe for them to walk to school were more likely to be active travelers. This finding is in agreement with previous studies which indicated that parental safety concerns were associated with increased car trips to school $(12,16,19)$. Further, as parental safety concerns in the present study were assessed based on children's perceptions our findings extend the results of previous studies that assessed this variable using parental responses (12, 16, 19). Interestingly this finding was not observed among high and technical school students, perhaps indicating that parental safety concerns diminish as children grow older.

Other children in the neighborhood walking to school was positively associated with elementary school's students active 
traveling to school at the multivariate level. In a recent prospective study, Hume et al. (22) found that children who had many friends in the area were more than twice as likely to increase their active commuting to school compared with other children. Whereas promoting road safety may be important for increasing elementary school's children active travel to school, targeting social factors (i.e. other children walking to school) may also be important in improving the efficacy of intervention programs.

Interpretation of the results of the present study would not be complete unless we acknowledge some limitations. First, children's mode of transport to school was assessed with only one question and did not include mixed modes of travel (e.g. walk and bus) or differentiated between travel to and travel from school. Second, no objective data were obtained that assess distance from children's home to school and other environmental factors including traffic from home to school or neighborhood characteristics. Third, the cross-sectional design of the study does not allow us to infer cause and effect relationships between hypothesized determinants and active traveling to school. Strengths of the present study include the presentation of data from a different population and geographical region and the large sample obtained across all levels of education and districts of the Republic of Cyprus.

This study indicated that prevalence of active traveling to school among Greek adolescents in Cyprus is much lower than estimates reported in other countries including North European countries. Factors including place of residence (urban and rural), parental safety concerns, adequate time in the morning to walk to school, and other children from the neighborhood walking to school for elementary school children were related to active travel to school. These factors should be appropriately targeted to promote active traveling to school in Cyprus and suggest that a multi-sector, multilevel approach is needed to successfully promote active traveling including the child, the family and Government Bodies including the Ministries of Education, Communications and Work, and Justice. More evidence from other European countries situated in the Mediterranean region are needed to complement these data.

\section{Acknowledgments}

Special thanks are due to the children who participated in this study, to the teachers who devoted their valuable time for data collection and to the two Inspectors of Home Economics of the Cyprus Ministry of Education, Ms Eva Neophytou and Ms Sandry Taliadorou.

\section{REFERENCES}

1. Strong WB, Malina RM, Blimkie CJ, Daniels SR, Dishman RK, Gutin $\mathrm{B}$, at al. Evidence based physical activity for school-age youth. J Pediatr. 2005 Jun;146(6):732-7.

2. Council on Sports Medicine and Fitness; Council on School Health. Active healthy living: prevention of childhood obesity through increased physical activity. Pediatrics. 2006 May;117(5):1834-42.

3. Tudor-Locke C, Ainsworth BE, Popkin BM. Active commuting to school: an overlooked source of childrens' physical activity? Sports Med. 2001;31(5):309-13.

4. Jago R, Baranowski T. Non-curricular approaches for increasing physical activity in youth: a review. Prev Med. 2004 Jul;39(1):157-63.

5. Pate RR, Davis MG, Robinson TN, Stone EJ, McKenzie TL, Young JC. Promoting physical activity in children and youth: a leadership role for schools: a scientific statement from the American Heart Association Council on Nutrition, Physical Activity, and Metabolism (Physical Activity Committee) in collaboration with the Councils on Cardiovascular Disease in the Young and Cardiovascular Nursing. Circulation. 2006 Sep 2;114(11):1214-24.

6. Cooper AR, Andersen LB, Wedderkopp N, Page AS, Froberg K. Physical activity levels of children who walk, cycle, or are driven to school. Am J Prev Med. 2005 Oct;29(3):179-84.
7. Lee MC, Orenstein MR, Richardson MJ. Systematic review of active commuting to school and children's physical activity and weight. J Phys Act Health. 2008 Nov;5(6):930-49.

8. Van der Ploeg HP, Merom D, Corpuz G, Bauman AE. Trends in Australian children traveling to school 1971-2003: burning petrol or carbohydrates? Prev Med. 2008 Jan;46(1):60-2.

9. Evenson KR, Huston SL, McMillen BJ, Bors P, Ward DS. Statewide prevalence and correlates of walking and bicycling to school. Arch Pediatr Adolesc Med. 2003 Sep;157(9):887-92.

10. Robertson-Wilson JE, Leatherdale ST, Wong SL. Social-ecological correlates of active commuting to school among high school students. J Adolesc Health. 2008 May;42(5):486-95.

11. Booth ML, Okely AD, Denney-Wilson E, Hardy LL, Dobbins T, Wen L-M, et al. Characteristics of travel to and from school among adolescents in NSW, Australia. J Paediatr Child Health. 2007 Nov;43(11):755-61.

12. Merom D, Tudor-Locke C, Bauman A, Rissel C. Active commuting to school among NSW primary school children: implications for public health. Health Place. 2006 Dec;12(4):678-87.

13. Tudor-Locke C, Ainsworth BE, Adair LS, Popkin BM. Objective physical activity of filipino youth stratified for commuting mode to school. Med Sci Sports Exerc. 2003 Mar;35(3):465-71.

14. Van Sluijs EM, Fearne VA, Mattocks C, Riddoch C, Griffin SJ, Ness A. The contribution of active travel to children's physical activity levels: cross-sectional results from the ALSPAC study. Prev Med. 2009 Jun;48(6):519-524.

15. Bere E, van der Horst K, Oenema A, Prins R, Brug J. Socio-demographic factors as correlates of active commuting to school in Rotterdam, the Netherlands. Prev Med. 2008 Oct;47(4):412-6.

16. Bringolf-Isler B, Grize L, Mäder U, Ruch N, Sennhauser FH, BraunFahrländer C; SCARPOL team. Personal and environmental factors associated with active commuting to school in Switzerland. Prev Med. 2008 Jan;46(1):67-73.

17. Cooper AR, Wedderkopp N, Wang H, Andersen LB, Froberg K, Page AS. Active travel to school and cardiovascular fitness in Danish children and adolescents. Med Sci Sports Exerc. 2006 Oct;38(10):1724-31.

18. Timperio A, Ball K, Salmon J, Roberts R, Giles-Corti B, Simmons D, et al. Personal, family, social, and environmental correlates of active commuting to school. Am J Prev Med. 2006 Jan;30(1):45-51.

19. Kerr J, Rosenberg D, Sallis JF, Saelens BE, Frank LD, Conway TL. Active commuting to school: associations with environment and parental concerns. Med Sci Sports Exerc. 2006 Apr;38(4):787-94.

20. McDonald NC. Children's mode choice for the school trip: the role of distance and school location in walking to school. Transportation. 2008 Jan;35(1):23-35.

21. Panter JR, Jones AP, van Sluijs EMF. Environmental determinants of active travel in youth: a review and framework for future research. Int $\mathrm{J}$ Behav Nutr Phys Act. 2008 Jun 23;5(1):34.

22. Hume C, Timperio A, Salmon J, Carver A, Giles-Corti B, Crawford D. Walking and cycling to school: predictors of increases among children and adolescents. Am J Prev Med. 2009 Mar;36(3):195-200.

23. Faulkner GE, Buliung RN, Flora PK, Fusco C. Active school transport, physical activity levels and body weight of children and youth: a systematic review. Prev Med. 2009 Jan;48(1):3-8.

24. Cavill N, Biddle S, Sallis JF. Health enhancing physical activity for young people: Statement of the United Kingdom Expert Consensus Conference. Pediatr Exerc Sci. 2001 Feb;13(1):12-25.

25. Lobstein TJ, James WPT, Cole TJ. Increasing levels of excess weight among children in England. Int J Obes Relat Metab Disord. 2003 Sep;27(9):1136-8.

26. Cole TJ, Bellizzi MC, Flegal KM, Dietz WH. Establishing a standard definition for child overweight and obesity worldwide: international survey. BMJ. 2000 May 6;320(7244):1240-3.

27. International Road Federation. The IRF world road statistics 2006: data 1999-2004. Geneva: IRF; 2006.

28. Department of Road Transport [Internet]. Nicosia: Cyprus Ministry of Communications and Work [cited 2010 Apr 10]. Available from: www. mcw.gov.cy/mcw/rtd/rtd.nsf/dmlindex_gr/dmlindex_gr?OpenDocument.

29. Rosenberg DE, Sallis JF, Conway TL, Cain KL, McKenzie TL. Active transportation to school over 2 years in relation to weight status and physical activity. Obesity. 2006 Oct;14(10):1771-6.

30. Martin SL, Lee SM, Lowry R. National prevalence and correlates of walking and bicycling to school. Am J Prev Med. 2007 Aug;33(2):98-105.

Received November 26, 2009

Accepted in revised form February 10, 2010 